\title{
ANALYZING THE FACTORS INFLUENCING TRUST IN A CONSTRUCTION PROJECT: EVIDENCE FROM A SINO-GERMAN ECO-PARK IN CHINA
}

\author{
Dedong WANG, Kaili LI*, Shaoze FANG \\ School of Management Engineering, Shandong Jianzhu University, 250101, Jinan, China
}

Received 23 January 2018; accepted 16 April 2018

\begin{abstract}
Trust is regarded as a critical feature and a central mechanism in business transactions, especially in the Chinese guanxi network. In this context, the major objective of this research is to explore the key factors influencing trust in different stages of a construction project from the perspectives of owners and consultants involved in a Sino-German eco-park in China. The analytic network process (ANP) was employed to assess which factors are most closely related to trust and to establish four models to meet the objective of this study. According to the ANP results, trust is strongly influenced by factors that are associated with the mutual interests between owners and consultants. In addition, there are certain differences in the priority of the factors influencing initial trust between owners and consultants, but these gaps gradually decrease over time. The weight of guanxi also decreases over time, and the owners' and consultants' guanxi transforms from out-group to in-group focused.
\end{abstract}

Keywords: trust, influence factors, guanxi, Sino-German eco-park, construction project, China, analytic network process (ANP).

\section{Introduction}

Trust has been found to be a key feature and a central mechanism in business transactions, especially in the Chinese context (Jin, Ling 2005). Trust is regarded as a rational choice, a social and cultural phenomenon, and a psychological status that is related to national values (Girmscheid, Brockmann 2010; Harris, Dibben 1999). In the new institutional economics system, Williamson (2000) divided institutions into four levels or categories: (1) social or culture embeddedness; (2) basic institutional environment; (3) institutions of governance; and (4) resource allocation and complementation. The first level, or the informal institution level, mainly includes the norms, customs, mores, and traditions, and has far-reaching impact on the other three levels (Williamson 2000). The second level, or the formal institution level, reflects the constitutions, laws, and property rights (Williamson 2000). Indeed, China is characterized by a relatively ineffective legal system, strong collectivism and high power distance (Cao, Lumineau 2015). It seems that formal institutions and informal institutions are complementary in China, whereas these institutions are independent in Western countries, where there is a greater focus on formal institutions and individualism. Additionally, Chinese people are more concerned with relationship marketing in "guanxi" networks that are deeply embedded in construction enterprises (Badi et al. 2017). On the one hand, in order to maintain a guanxi network, the Chinese pay more attention to "mianzi" and "renqing" in an exchange (Luo 1997; Hwang 1987; Wang 2007). On the other hand, they prefer to minimize ambiguity through mutual discussion or mediation rather than with formal contract agreements (Sullivan, Peterson 1982) due to the high imperfections in institutions and the legal system (Luo 1997; Wang 2007). In summary, trust plays a vital role in Chinese construction projects, and Chinese people may regard the use of contract agreements as evidence of mistrust and the use of conferment as enhancing trust (Sullivan, Peterson 1982) especially in resolving ambiguous and unpredictable problems. Meanwhile, guanxi, as an informal institution, has an important influence on trust. Hence, the formation of trust is influenced by the institutional environment and its efficiency has a strong impact on the field of construction project management.

In recent years, a considerable amount of literature related to trust has emerged addressing construction projects. These studies mainly emphasize the efficiency of trust. The results suggest that trust is the core factor of interpersonal relationships and transactions (Girmscheid,

${ }^{\star}$ Corresponding author. E-mail: 2813137482@qq.com 
Brockmann 2010; Cheung et al. 2011) and is a basic component and facilitator of social interaction. Furthermore, trust is regarded as a predictor of project performance, project effectiveness, stakeholder satisfaction, creativity, problem resolution, open knowledge and information, and project success (Rezvani et al. 2016). In an inter-organizational relationship, trust is regarded as a key factor that positively affects external knowledge acquisition, promotes project innovation, lessens project risk, reduces barriers to interdependence, and supports information exchange without the full monitoring of project team members (Maurer 2010; Thorgren, Wincent 2011). In stakeholder-oriented governance, a higher level of trust reduces transaction costs (Thorgren, Wincent 2011). Trust in a contractual relationship can facilitate the exchange of information and reduce the need for external control and its associated costs (Aubert, Kelsey 2000). However, Harris and Dibben (1999) consider the development of trust to be an iterative process in which the achievement of trust in earlier stages promotes the development of trust in later stages. In the stage of initial trust, reputation, common experience, and working expectations have important impacts (Campo et al. 2014). Simultaneously, open information and communication sharing, self-ability, detailed contractual agreements, performance supervision, and severe sanctions for non-conformance strengthen the motivation for cooperation among team members (Buvik, Rolfsen 2015; Kadefors 2004), thus improving the level of trust in early stages.

Although previous researchers have made achievements in the field of the contributions and driving factors of trust, there is still a gap regarding the establishment and development of trust among construction project participants based on the Chinese guanxi network. This paper fills that gap. First, the factors influencing trust were divided into personal propensity, ability, benevolence and integrity categories based on a literature review and interviews. Then, the interdependence of elements was discussed to establish an analytic network process (ANP) network model. To this end, an expert panel was organized that brought together the main participants (owners and consultants) in a Sino-German eco-park. During this process, the respondents identified the elements and established their relationships with each other. Meanwhile, data were collected by the rule of fundamental scale. The collected data were analyzed using Super Decisions ${ }^{\circledR}$ software version 2.6.0 to assess the prioritization of the factors influencing trust. The findings of this paper are expected to guide and provide a reference for future practice, especially in cross-border projects.

\section{Theoretical background}

\subsection{Key factors influencing trust}

Trust is regarded as multidimensional and dynamic, and its formation is an iterative process. Key factors influencing trust are not constant but are changeable based on an increase in cooperation duration. Campo et al. (2014) divide trust into the periods before initiating the agreement and during the development of the agreement. Poppo et al. (2008) classify the origins of trust into the shadow of the past and the shadow of the future. Based on the research results of Mayer et al. (1995), the factors of perceived trustworthiness, except for the personal propensity to trust, are grouped into the ability, benevolence and integrity categories. Personal propensity might be considered as a willingness to trust others, and it may be influenced by prior experience, reputation, and cooperation expectations. Ability reflects a partner's skill, competence and characteristics (for instance, enterprise qualifications, knowledge, and communication), and it has a strong influence on some specific domains. Benevolence suggests that a partner has some attachment to others and is believed to want to do good to the others. It is reflected by information availability, information quality, being thoughtful, and emotional investment. Integrity involves people's perception that a commitment will be fulfilled and will adhere to the mutually agreed upon principles and guidelines, such as legal provision, contracts, and industry practice. These trust-influencing factors are specifically described in Table 1.

Table 1. Key factors influencing trust

\begin{tabular}{|c|c|c|}
\hline Clusters & $\begin{array}{l}\text { Influence } \\
\text { factors }\end{array}$ & Definition \\
\hline \multirow{3}{*}{ 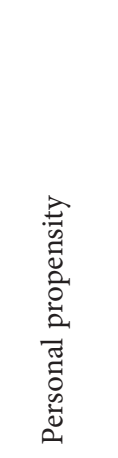 } & $\begin{array}{l}\text { Prior experience } \\
\text { (P1) }\end{array}$ & $\begin{array}{l}\text { Prior experiences are developed over time through a history of mutual interactions and } \\
\text { cooperation, and they serve a facilitating role in establishing trust through an interaction } \\
\text { with continuity (Poppo et al. 2008). Positive prior experiences have a substantial impact on } \\
\text { the development of trust, especially in the beginning stages of an inter-organizational project } \\
\text { (Buvik, Rolfsen 2015; Maurer 2010). }\end{array}$ \\
\hline & Reputation (P2) & $\begin{array}{l}\text { Reputation is second-hand information in which a project partner cannot evaluate his/ } \\
\text { her partner's traits using direct evidence. If the information is evaluated positively, then the } \\
\text { reputation and image of the partners will be positive. Kwon and Suh (2004) stated that a } \\
\text { partner's reputation has a strong and positive influence on the process of building trust. }\end{array}$ \\
\hline & $\begin{array}{l}\text { Cooperation } \\
\text { expectation }(\mathrm{P} 3)\end{array}$ & $\begin{array}{l}\text { Cooperation expectation is a vision of future work and is closely related to work rewards. } \\
\text { Laan et al. (2012) found that the prospects of future cooperation have a significant influence } \\
\text { on trust in construction projects. }\end{array}$ \\
\hline
\end{tabular}


End of Table 1

\begin{tabular}{|c|c|c|}
\hline Clusters & $\begin{array}{l}\text { Influence } \\
\text { factors }\end{array}$ & Definition \\
\hline & $\begin{array}{l}\text { Prior experience } \\
\text { (P1) }\end{array}$ & $\begin{array}{l}\text { Prior experiences are developed over time through a history of mutual interactions and cooperation, } \\
\text { and they serve a facilitating role in establishing trust through an interaction with continuity (Poppo } \\
\text { et al. 2008). Positive prior experiences have a substantial impact on the development of trust, espe- } \\
\text { cially in the beginning stages of an inter-organizational project (Buvik, Rolfsen 2015; Maurer 2010). }\end{array}$ \\
\hline & Reputation (P2) & $\begin{array}{l}\text { Reputation is second-hand information in which a project partner cannot evaluate his/her partner's } \\
\text { traits using direct evidence. If the information is evaluated positively, then the reputation and image } \\
\text { of the partners will be positive. Kwon and Suh (2004) stated that a partner's reputation has a strong } \\
\text { and positive influence on the process of building trust. }\end{array}$ \\
\hline & $\begin{array}{l}\text { Cooperation } \\
\text { expectation (P3) }\end{array}$ & $\begin{array}{l}\text { Cooperation expectation is a vision of future work and is closely related to work rewards. Laan } \\
\text { et al. ( } 2012 \text { ) found that the prospects of future cooperation have a significant influence on trust in } \\
\text { construction projects. }\end{array}$ \\
\hline \multirow{3}{*}{ 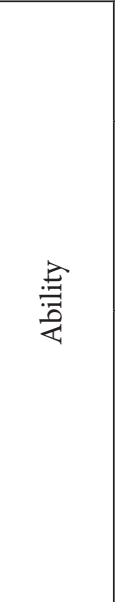 } & $\begin{array}{l}\text { Enterprise } \\
\text { qualification } \\
\text { (A1) }\end{array}$ & $\begin{array}{l}\text { The enterprise's qualifications are an important reference for evaluating an enterprise during the bidding } \\
\text { process. The enterprise's personnel structure, professional skills, management level, financial situation, } \\
\text { and previous project performance can be considered components that affect enterprise qualifications. }\end{array}$ \\
\hline & Knowledge (A2) & $\begin{array}{l}\text { Knowledge is viewed as an important foundation in organizational social capital (Lee et al. 2015). } \\
\text { Commonly, professional knowledge can be categorized as business and technology expertise (Lee } \\
\text { et al. 2015), but it is very difficult to establish trust among collaboration members due to asymmetric } \\
\text { and mismatched knowledge levels (Patnayakuni et al. 2007). Thus, the knowledge levels among } \\
\text { organizations or individuals are regarded as being closely associated with trust (Lee et al. 2015). }\end{array}$ \\
\hline & $\begin{array}{l}\text { Communication } \\
\text { (A3) }\end{array}$ & $\begin{array}{l}\text { Communication is a process in which members among inter-organizations can exchange information } \\
\text { and enhance each other's mutual understanding (Tzafrir et al. 2004). Communication is also a } \\
\text { form of social interaction that raises the level of knowledge sharing for successful information } \\
\text { system development projects (Park, Lee 2014). Effective communication not only helps form } \\
\text { a good relationship (for instance, by increasing the satisfaction and intimacy of relationships) } \\
\text { (Emmers-Sommer 2004) but also maintains it (for instance, by reducing the conflicts among team } \\
\text { members) (Dawes, Massey 2005). Open communication enables team members to develop stronger } \\
\text { relationships, leading to higher trust levels (Buvik, Rolfsen 2015). }\end{array}$ \\
\hline \multirow{4}{*}{ 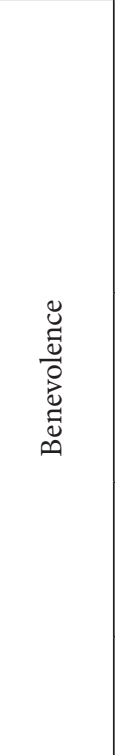 } & $\begin{array}{l}\text { Information } \\
\text { availability (B1) }\end{array}$ & $\begin{array}{l}\text { Information consists of both sharing operational and financial information (such as transaction costs, } \\
\text { plans, and scheduling) among partners and exchanging vital strategic information (such as forecasting } \\
\text { data) (Kwon, Suh 2005). If information sharing between partners is lacking, then uncertainty and } \\
\text { opportunistic behavior may increase (Kwon, Suh 2005). Relevant information is available to all } \\
\text { partners within inter-organizations, including public and private information (Chen et al. 2011; } \\
\text { Uzzi, Lancaster 2003). However, extremely open private information shared with other partners with } \\
\text { whom there is little shared experience is likely to lead to negative consequences unless it is clear that } \\
\text { the principle of information sharing is understandable to all partners (Alexopoulos, Buckley 2013). }\end{array}$ \\
\hline & $\begin{array}{l}\text { Information } \\
\text { quality (B2) }\end{array}$ & $\begin{array}{l}\text { Information quality requires key information attributes during exchanges, such as accuracy, } \\
\text { relevance, timeliness, reliability, understandability, accessibility, and ease of use (Ghosh, Fedorowicz } \\
\text { 2008). Furthermore, these attributes must create a certain value for each partner in the inter- } \\
\text { organizational relationship (Ghosh, Fedorowicz 2008). Meanwhile, inter-organizational cooperation } \\
\text { will extend the need to share confidential information (Hallikas et al. 2002). }\end{array}$ \\
\hline & $\begin{array}{l}\text { Being } \\
\text { thoughtful (B3) }\end{array}$ & $\begin{array}{l}\text { Wei et al. (2008) suggested that being thoughtful and emotional investment are essential attitudes } \\
\text { for the formation of affect-based trust. If a partner treats other partners with care and concern, then } \\
\text { he/she will be willing to understand the other partners' needs and feelings, and the partners will be } \\
\text { treated in the same way. }\end{array}$ \\
\hline & $\begin{array}{l}\text { Emotional } \\
\text { investment (B4) }\end{array}$ & $\begin{array}{l}\text { Emotion is a perception of consciousness and is driven by personal feeling. Emotional investments } \\
\text { can reduce defensiveness, unhealthy disruption and competitiveness; eliminate friction; enhance } \\
\text { team morale and spirit; and improve the trust in working relationships (Wei et al. 2008). }\end{array}$ \\
\hline \multirow{3}{*}{ 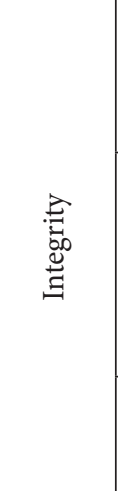 } & $\begin{array}{l}\text { Legal provision } \\
\text { (I1) }\end{array}$ & $\begin{array}{l}\text { Arrighetti et al. (1997) stated that the existence of reliable contract law can benefit the development } \\
\text { of trust in business relationships, as relationships based on legal rules can significantly lower the } \\
\text { inherent trust risk. Meanwhile, the formal system can ensure that the partners evaluate and maintain } \\
\text { the relationship, increase perceptions of equity and reciprocity, and facilitate trust (Kadefors 2004). }\end{array}$ \\
\hline & Contract (I2) & $\begin{array}{l}\text { The contract defines the rights, obligations, long-term commitments, project deliverables, punishments } \\
\text { for opportunism and the adaptive process for resolving unforeseeable problems between the partners } \\
\text { of a contract (Cao, Lumineau 2015; Argyres, Mayer 2007; Lusch, Brown 1996). The contract mitigates } \\
\text { operational misunderstandings and improves operational transparency, as codified provisions are } \\
\text { regarded as a benchmark with which a partner can effectively monitor ongoing operations and quickly } \\
\text { identify potential deviations (Seggie et al. 2013; Cavusgil et al. 2004; Lumineau, Henderson 2012). }\end{array}$ \\
\hline & $\begin{array}{l}\text { Industry } \\
\text { practice (I3) }\end{array}$ & $\begin{array}{l}\text { Industry practice is an informal system, and it mainly includes certain aspects, such as certain parties } \\
\text { among project partners, investigations and studies related to projects, leadership inspections and } \\
\text { project performance evaluations. }\end{array}$ \\
\hline
\end{tabular}




\subsection{Guanxi network}

The guanxi network is a philosophical ideology that is deeply influenced by Confucianism, which is the principal value system that directs Chinese exchanges and behaviors. Guanxi not only involves blood-based relationships but also exists in ganqing or emotional attachments, which include direct or indirect relationships with colleagues, friends, and schoolmates (Wang 2007; Luo 1997; Styles, Ambler 2003; Badi et al. 2017). Specifically, Chinese people have a strong tendency to divide people into different levels and to treat them differently based on their in-group or out-group status (Triandis 1989). Only the members of in-groups can utilize relational resources, while out-groups are excluded (Yang et al. 2011). As Peng and Luo (2000) emphasize, a strong guanxi includes very important resources and perhaps even factors critical for success. There are multiple roles between owners and consultants. On the one hand, they are members of agent relationships according to the contract. On the other hand, they may also be members of a special guanxi, such as a clan, friend or schoolmate relationship in the guanxi network. These special relationships can strongly influence building trust and executing contracts. Meanwhile, owners or consultants can convince their partner(s) to perfectly fulfil the obligations of both parties without signing the contract based on reputation, competence or social influence, but the cooperative relationship between partners is still based on a contract. In other words, work first and then sign the contract. The phenomenon indicates that the partners must follow certain unwritten rules in the guanxi network.

"Mianzi" (face) and "renqing" (favor) are important factors and tools in extending and manipulating the guanxi network (Luo 1997; Hwang 1987). Mianzi is regarded as the tactic of protecting one's own reputation since it represents social currency and personal status in the guanxi network (Luo 1997; Hammond, Glenn 2004). In the guanxi network, participants must abide by the promise and obligation of reciprocity and equity. Otherwise, they will lose face and hurt their social status (Wang 2007). Renqing "is a unique term in Chinese culture, often referring to the resource that one can present to another person as a gift in social exchange process, and a set of social norms that one should follow to get along well with other people" (Hwang 1987). Renqing has a reciprocity characteristic where a partner who receives a favor from another partner must return a renqing to the benefactor when appropriate (Hwang 1987). Renqing is a debt that is not a cash debt, which can be equally repaid, since the value of a renqing cannot be accurately assessed. If the value that you repay is similar to or greater than the value that you received, you adhere to the rule of reciprocity that decrees that "if you have got a drop of favor from other people, you should return a foundation of favour" (Hwang 1987). If the value that you repay is less than the value that you received, you violate the rule of reciprocity and equity, thus losing mianzi and hurting the emotions of friends in the guanxi network (Luo 1997). The principles of the guanxi network are similar to those of social exchange theory. One of the basic principles of social exchange theory is that relationships will evolve into trust, loyalty and mutual commitment over time (Cropanzano, Mitchell 2005). In the process, the partners must follow the rule of reciprocity and fairness. If not, they will be punished by their social relationships (Blau 1965; Cropanzano, Mitchell 2005).

To sustain mianzi and renqing, both the in-group and out-group will comply with the rule of reciprocity and equality in the guanxi network. However, these groups have certain differences in the process of building trust. The in-group organizations have a more intimate relationship than the out-group ones in the early stages of a project's construction. Thus, we divide the relationship of inter-organizations into in-group and out-group. Trust is shaped by special guanxi or high confidence between organizations of an in-group and by the general procedure between out-group organizations.

\section{Research method}

ANP is a decision methodology that can derive the priority weights of the factors influencing trust through a reciprocal pairwise comparison process. ANP is an extension and improvement of the analytic hierarchy process (AHP) and considered an ideal tool for resolving complex decision problems (Saaty 2004). ANP, which different from the hierarchical form of AHP, is a network form in a problem resolution structure model. In an ANP network, the network links among the decision clusters and elements express dependencies. The network links between elements of the same decision cluster represent the inner dependencies while the links between elements of one decision cluster and other decision clusters represent the outer dependencies (Saaty 2004).

The reason that ANP is deemed to be an ideal methodology for resolving the priorities of factors influencing trust is that ANP is more suitable for resolving complex problems that contain multi-criterion and multi-elements in real life. ANP is a theory of the relative measurement of intangible criteria (Saaty, Sagir 2009). Its network structure can express the dependencies among related-elements and allows decision makers to compare the priorities among related-elements through a reciprocal comparison process. In a reciprocal comparison process, ANP helps determine the influence by which two elements have more or less influence on a third element based on the same criteria (Saaty 2004). At the same time, an ANP network model not only considers the influence of an element on other elements but also incorporates the influence of other elements on that element.

ANP has been extensively and effectively used in many domains that require interactions among different elements, including assessing stakeholders' influence (Aragonés-Beltrán et al. 2017), analyzing risk (Chen et al. 2011), and evaluating performance (Chen, Hong 2007). The ANP attributes criteria and alternatives (all called elements) in the network to a cluster and is a tool for solving problems. All the elements in the network can 
be grouped according to different relationships, such as feedback and interdependence relationships within and between clusters (Aragonés-Beltrán et al. 2014). The complicated model provides more accurate and reliable decisions in complex settings.

In the study, the ANP model is used to analyze the factors that influence the trust relationship between owners and consultants. The accuracy and reliability of the method can be evaluated according to relative scales from Saaty's Fundamental 1 to 9 scale that measure the importance of every parameter (see Table 2). We identify the elements that influence trust according to a thorough literature review. Then, we group the elements into different clusters with common features and calculate the priorities among clusters and among elements of the same cluster. Finally, we obtain the unweighted supermatrix, the weighted supermatrix, and the limited supermatrix using Super Decisions ${ }^{\circledR}$ software.

Table 2. From 1 to 9 fundamental scale

\begin{tabular}{|c|l|}
\hline Priority of importance & \multicolumn{1}{c|}{ Definition } \\
\hline 1 & Equal importance \\
\hline 3 & Moderate importance \\
\hline 5 & Strong importance \\
\hline 7 & Very strong importance \\
\hline 9 & Extreme importance \\
\hline $\begin{array}{l}\text { The priorities of importance of } 2,4,6 \text {, and } 8 \text { are between } 1, \\
3,5,7 \text {, and } 9 .\end{array}$ \\
\hline
\end{tabular}

\section{Case study}

This case study has been implemented at a Sino-German eco-park in Qingdao city, Shandong province, China. The Sino-German eco-park is a joint project between the Chinese and German governments and applies German standards based on Chinese practice in the process of construction. Its construction period is from 2010 to 2020 . The types of projects in the Sino-German eco-park include industrial projects, residential projects, roads, greening projects and infrastructure projects. Every project is overseen by a dedicated owner and consultant. To obtain sufficient and effective data in the study, we selected and invited 20 project managers who have conducted different projects to form an expert panel for the period from March-April 2017. Of the 20 respondents, 2 respondents had been working as owners for more than 20 years, 3 for 15-20 years, 4 for 10-15 years, and 1 for 5-10 years. One respondent had been working as a consultant for more than 20 years, 2 for $15-20$ years, 4 for $10-15$ years, and 3 for 5-10 years. Thus, the respondents have very rich practical and theoretical experience.

Our case study organized an in-depth interview with the expert panel that was conducted by the primary author. The interview included two parts. First, we identified the relationships between elements. Before we finished the work of identifying elements and clusters according to the existing literature, the respondents determined these elements and their relationships with each other. If there was any inconsistency, the expert panel discussed it until the consensus score was approved by more than 70 percent of respondents. Second, we compared the priority of elements or clusters using Saaty's Fundamental 1 to 9 Scale (see Table 2). If its average score was substantially different from the score of 70 percent of respondents, the score was discussed again; otherwise, the average score was used as the final score. The process lasted more than 3 hours, and the responses were recorded digitally and transcribed. Based on the results that we have achieved, the next steps of case study include: (1) Building a relationship matrix of all elements of the network; (2) Comparing the priorities between relevant elements; and (3) Determining the final priorities of the elements in the ANP model.

\subsection{Building a relationship matrix with all of the network elements}

A relationship matrix (zero-one dependence matrix) can reflect whether there is a direct relationship between elements. In the zero-one dependence matrix, the value of 0 or 1 in position $r_{i j}$ represents whether one element is dependent on the other. If $r_{i j}=1$, the element of row $i$ has an influence on the element of column $j$. Otherwise, the element of row $i$ does not have an influence on the element of column $j$. For example, the element of P1 impacts P2, P3, A3, B1, B2, B3, B4, I3, G1 and G2. Thus, the matrix represents the interdependence of factors influencing trust (see Table 3). Meanwhile, the interdependence of factors influencing trust is used in the ANP network model (see Figure 1).

\subsection{Comparing the priorities between relevant elements}

Based on the ANP network model, a questionnaire was designed to assess the impact of each element on other elements to which it is related. For this purpose, the respondents provided a pairwise comparison between elements required by the ANP model. A sample from the questionnaire is, "Comparing the elements (such as A1

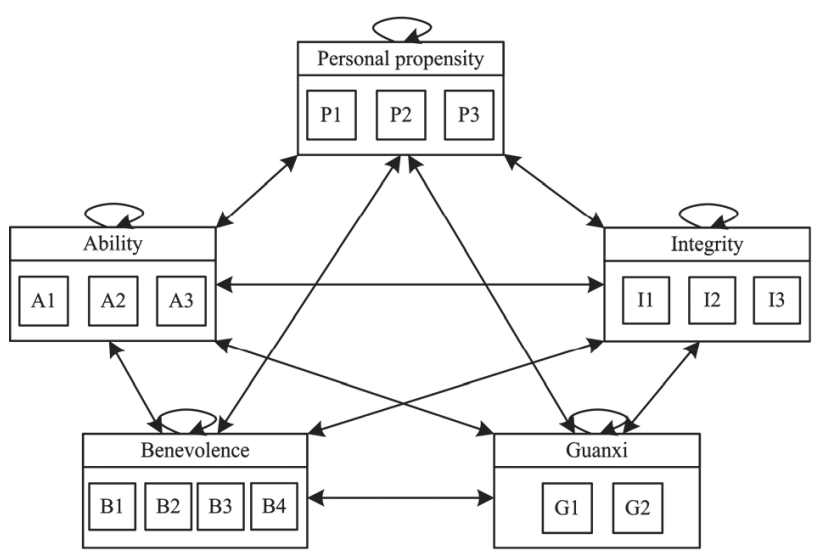

Figure 1. Interdependence of the elements in the ANP network model 
Table 3. Relationship matrix of all elements of the network

\begin{tabular}{|c|c|c|c|c|c|c|c|c|c|c|c|c|c|c|c|}
\hline & P1 & P2 & P3 & A1 & A2 & A3 & B1 & B2 & B3 & B4 & I1 & I2 & I3 & G1 & G2 \\
\hline P1 & 0 & 1 & 1 & 0 & 0 & 1 & 1 & 1 & 1 & 1 & 0 & 0 & 1 & 1 & 1 \\
\hline P2 & 0 & 0 & 1 & 0 & 0 & 1 & 1 & 1 & 1 & 1 & 0 & 0 & 1 & 1 & 1 \\
\hline P3 & 0 & 0 & 0 & 0 & 0 & 1 & 1 & 1 & 1 & 1 & 0 & 0 & 1 & 1 & 1 \\
\hline A1 & 0 & 0 & 1 & 0 & 1 & 1 & 1 & 1 & 1 & 1 & 0 & 1 & 0 & 1 & 1 \\
\hline A2 & 0 & 0 & 1 & 0 & 0 & 1 & 1 & 1 & 1 & 1 & 0 & 1 & 0 & 1 & 1 \\
\hline A3 & 0 & 0 & 1 & 0 & 1 & 0 & 1 & 1 & 1 & 1 & 0 & 1 & 0 & 1 & 1 \\
\hline B1 & 0 & 0 & 1 & 0 & 1 & 1 & 0 & 1 & 1 & 1 & 0 & 0 & 0 & 1 & 1 \\
\hline B2 & 0 & 0 & 1 & 0 & 1 & 1 & 1 & 0 & 1 & 1 & 0 & 0 & 0 & 1 & 1 \\
\hline B3 & 0 & 0 & 1 & 0 & 0 & 1 & 1 & 1 & 0 & 1 & 0 & 0 & 0 & 1 & 1 \\
\hline B4 & 0 & 0 & 1 & 0 & 0 & 1 & 1 & 1 & 1 & 0 & 0 & 0 & 0 & 1 & 1 \\
\hline I1 & 0 & 0 & 1 & 0 & 0 & 1 & 1 & 1 & 1 & 1 & 0 & 1 & 1 & 1 & 1 \\
\hline I2 & 0 & 0 & 1 & 0 & 0 & 1 & 1 & 1 & 1 & 1 & 0 & 0 & 1 & 1 & 1 \\
\hline I3 & 0 & 0 & 1 & 0 & 0 & 1 & 1 & 1 & 1 & 1 & 0 & 0 & 0 & 1 & 1 \\
\hline G1 & 1 & 1 & 1 & 1 & 1 & 1 & 1 & 1 & 1 & 1 & 1 & 1 & 1 & 0 & 1 \\
\hline G2 & 1 & 1 & 1 & 1 & 1 & 1 & 1 & 1 & 1 & 1 & 1 & 1 & 1 & 1 & 0 \\
\hline
\end{tabular}

Enterprise qualification, A2 Knowledge) in the cluster "Ability" based on their impact on the element P3 Cooperation expectation, which one has a greater influence and by how much?" consultants' opinions showed that owners' A1 Enterprise qualification has a stronger impact than A2 Knowledge on the element P3 Cooperation expectation during the stage of initial trust. The trust influencing factor and priority raw data were collected with a questionnaire.

\subsection{Determining the final element priorities in the ANP model}

All the raw data were inputted into Super Decisions ${ }^{\circledR}$ software, then the software output the individual results and the inconsistency index of each expert through a certain procedure. Meanwhile, we can obtain the unweighted supermatrix, the weighted supermatrix and the limited supermatrix to determine the element priorities in the ANP model. The final element priorities in the different stages are shown in Tables 5 and 6 .

\section{Results and discussion}

The limited supermatrix was obtained via the repeated iteration of the weighted supermatrix until their outputs converged. Hence, the elements of each column of the limited supermatrix represent the final weights of the factors influencing trust. Based on these results, the purpose of this research was twofold. First, we investigated the priorities of factors influencing trust based on the case of the Sino-German eco-park. Second, we explored how these factors drive trust's establishment and development from different perspectives in different stages.

\subsection{The priorities of factors influencing initial trust for owners and consultants}

The detailed results regarding the priorities of factors influencing initial trust for owners and consultants are displayed in Table 4 . In the process of establishing trust, our research results reveal that the viewpoints of owners and consultants have certain differences regarding the priorities of factors influencing trust. Owners pay more attention to ability (its cluster weight is 0.415 ), while consultants focus more on integrity (its cluster weight is 0.402 ). The reasons include the need for more dependence and reliability for owners and greater attention to fairness and safeguards for consultants. These factors are related to each party safeguarding their self-interests. For owners, in the initial stage of building trust, integrity is the second most important cluster (its cluster weight is 0.175 ), especially contracts and legal provisions, whereas industry practice has low priority (their normalized clusters are $0.540,0.375$ and 0.085 , respectively). From consultants' perspective, contracts and legal provisions are almost equally important, and their importance far exceeds that of industry practice (their normalized clusters are 0.483 , 0.463 and 0.053 , respectively). Generally, owners select consultants through bidding and are responsible for the drafting of contractual agreements. Likewise, legal systems are the basis of contract implementations through which exchange partners can protect themselves from opportunism by appealing to the legal system (Joskow 1987; Zhou, Poppo 2010). There is an agency relationship between owners and consultants in which consultants have the ability to make up for owners' needs. In the situation of extremely unequal professional knowledge, a stronger professional ability of the consultant will result in higher 
Table 4. Final priorities of the factors that influence initial trust for owners and consultants

\begin{tabular}{|c|c|c|c|c|c|c|c|c|}
\hline & \multicolumn{4}{|c|}{ From the owners' perspective } & \multicolumn{4}{|c|}{ From the consultants' perspective } \\
\hline $\begin{array}{l}\text { Influence } \\
\text { factors }\end{array}$ & $\begin{array}{l}\text { Limit } \\
\text { matrix }\end{array}$ & $\begin{array}{l}\text { Weight of } \\
\text { cluster }\end{array}$ & $\begin{array}{l}\text { Normalized } \\
\text { by cluster }\end{array}$ & Normalized & $\begin{array}{l}\text { Limit } \\
\text { matrix }\end{array}$ & $\begin{array}{l}\text { Weight of } \\
\text { cluster }\end{array}$ & $\begin{array}{c}\text { Normalized } \\
\text { by cluster }\end{array}$ & Normalized \\
\hline A1 & 0.190 & \multirow{3}{*}{0.415} & 0.459 & 0.295 & 0.112 & \multirow{3}{*}{0.162} & 0.694 & 0.183 \\
\hline $\mathrm{A} 2$ & 0.136 & & 0.328 & 0.211 & 0.014 & & 0.086 & 0.023 \\
\hline A3 & 0.088 & & 0.212 & 0.136 & 0.036 & & 0.220 & 0.058 \\
\hline B1 & 0.010 & \multirow{4}{*}{0.023} & 0.443 & 0.015 & 0.003 & \multirow{4}{*}{0.016} & 0.167 & 0.004 \\
\hline B2 & 0.009 & & 0.400 & 0.014 & 0.002 & & 0.137 & 0.004 \\
\hline B3 & 0.002 & & 0.105 & 0.004 & 0.007 & & 0.436 & 0.012 \\
\hline B4 & 0.001 & & 0.052 & 0.002 & 0.004 & & 0.259 & 0.007 \\
\hline I1 & 0.066 & \multirow{3}{*}{0.175} & 0.375 & 0.101 & 0.186 & \multirow{3}{*}{0.402} & 0.463 & 0.304 \\
\hline I 2 & 0.094 & & 0.540 & 0.146 & 0.194 & & 0.483 & 0.317 \\
\hline I3 & 0.015 & & 0.085 & 0.023 & 0.021 & & 0.053 & 0.035 \\
\hline P1 & 0.008 & \multirow{3}{*}{0.034} & 0.241 & 0.013 & 0.008 & \multirow{3}{*}{0.034} & 0.233 & 0.013 \\
\hline $\mathrm{P} 2$ & 0.013 & & 0.371 & 0.020 & 0.012 & & 0.368 & 0.020 \\
\hline P3 & 0.013 & & 0.388 & 0.021 & 0.013 & & 0.399 & 0.022 \\
\hline
\end{tabular}

dependence and trust from the owner to the consultant. Owners are more concerned with knowledge than consultants (their normalized clusters are 0.328 and 0.086 , respectively). Furthermore, owners and consultants know their partners' fiscal capacities, personal structures and communication mechanisms at the start. Therefore, both owners and consultants think highly of enterprise qualifications (their normalized clusters are 0.459 and 0.694 , respectively). If these abilities meet the partners' requirements, both sides will make a good impression, facilitating the formation of initial trust. If they lack cooperative experience in unique project organization settings, they may depend more on their expectations and predictions (Gulati 1995). The cooperation expectation and reputation have higher weights in the cluster of personal propensity for owners and consultants (their normalized clusters are 0.388 and 0.371 , respectively, from the perspective of owners, and 0.399 and 0.368 respectively from the perspective of consultants). Once they have satisfactory prior experience, the inter-organizational relationship quality is deeply influenced by prior interactions among participating organizations since the prior experience determines their familiarity and trust development (Buvik, Rolfsen 2015). Due to the lack of in-depth communication and interaction between owners and consultants, affectionbased trust may be formed by affection-based guanxi. To a certain extent, affection-based trust emphasizes certain social behaviors that are not positive and may harm the cultivation of social honesty and the credit system (Chen et al. 2013). Moreover, the results show that the influence of benevolence on initial trust is not prominent. The priorities of factors influencing initial trust for owners and consultants are shown in Figure 2 and Figure 3, respectively.

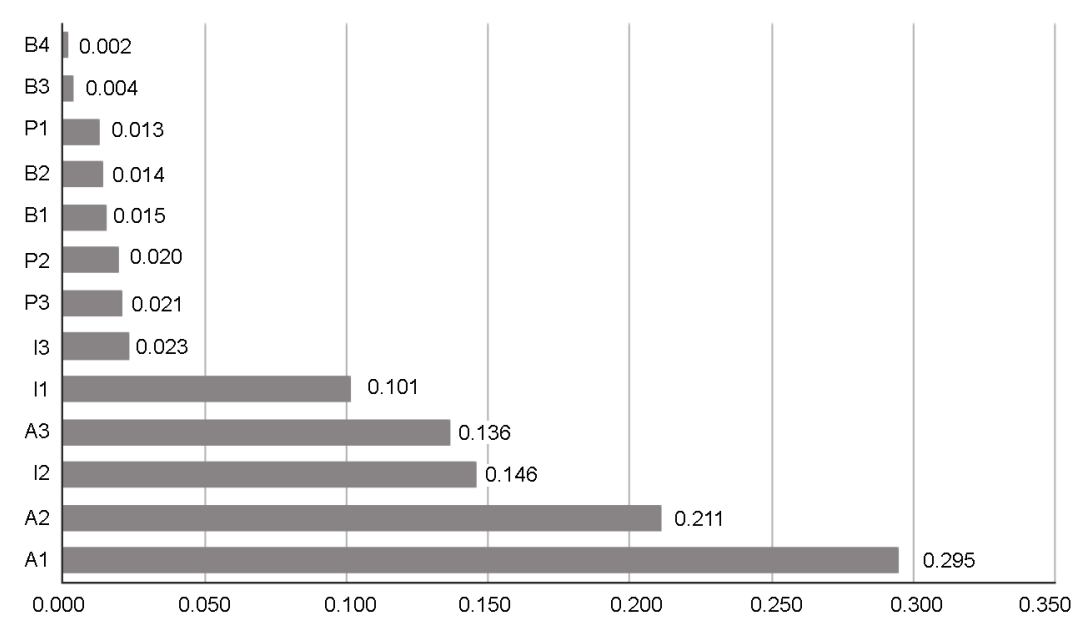

Figure 2. Priority of the factors influencing initial trust for owners 


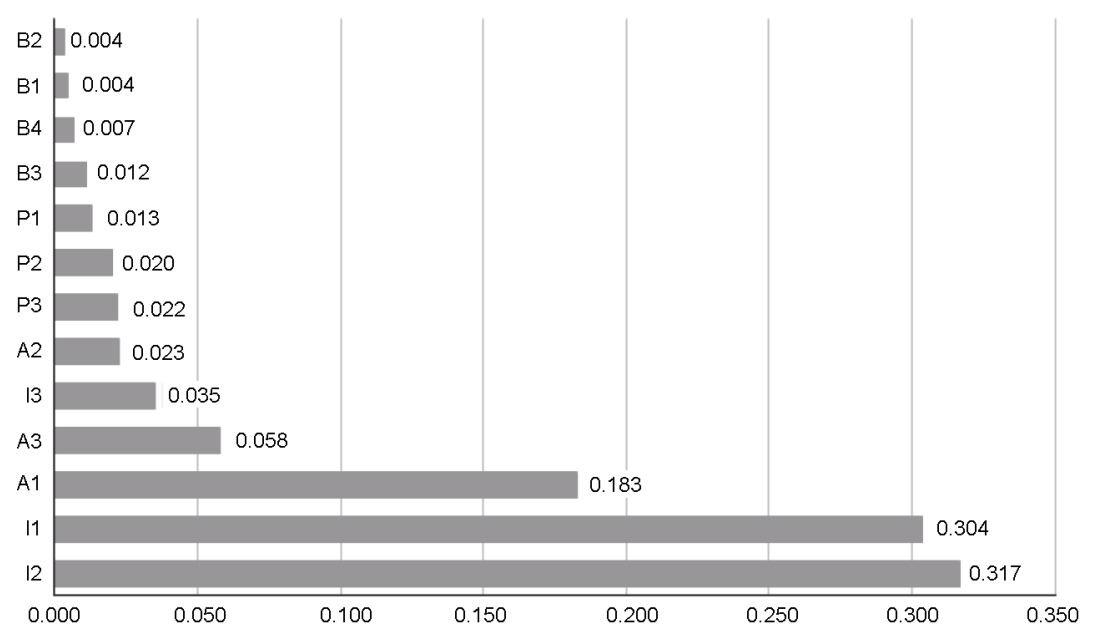

Figure 3. Priority of the factors influencing initial trust for consultants

\subsection{The priorities of factors influencing developing trust for owners and consultants}

Over time, the priorities of factors influencing trust have undergone great changes (see Table 5). Owners and consultants consistently assert that the prioritization of factors influencing trust is in the order ability, benevolence, personal propensity and integrity. As a relationship develops, each partner has enough time to repeatedly interact. Communication and trust create a strengthened circle, where open communications build trust, which further facilitates more open communications and more trust (Buvik, Rolfsen 2015). In conflict settings, particularly, the victim may choose to forgive their offender if the offender makes a sincere commitment to rectify their mistake through repeated and full communication. Thus, communication can dissolve conflict and increase mutual trust. Communica- tion is the most important factor in the clusters of ability (its normalized cluster is 0.462 for owners and 0.543 for consultants). Owners are concerned with the knowledge ability of consultants at all times due to the information asymmetry (its normalized cluster is 0.41 in the process of developing trust). As the cooperation length increases, the partners have more interactions and accumulate experiences in dealing with each other, which may improve their understanding of each other (Mayer, Argyres 2004; Mesquita, Brush 2008; Dyer, Chu 2000). Moreover, these interactions and experiences, which is a cumulative processes through learning between owners and consultants, form the primary understructure for trust development and provide norms related to the moral character of the partners (Yuan et al. 2010; Cao, Lumineau 2015). Furthermore, partners may make specific investments in the

Table 5. Final priorities of the factors that influence the development of trust for owners and consultants

\begin{tabular}{|c|c|c|c|c|c|c|c|c|}
\hline \multirow[b]{2}{*}{$\begin{array}{l}\text { Influence } \\
\text { factors }\end{array}$} & \multicolumn{4}{|c|}{ From the owners' perspective } & \multicolumn{4}{|c|}{ From the consultants' perspective } \\
\hline & $\begin{array}{l}\text { Limit } \\
\text { matrix }\end{array}$ & $\begin{array}{l}\text { Weight of } \\
\text { clusters }\end{array}$ & $\begin{array}{l}\text { Normalized } \\
\text { by cluster }\end{array}$ & Normalized & $\begin{array}{l}\text { Limit } \\
\text { matrix }\end{array}$ & $\begin{array}{l}\text { Weight of } \\
\text { clusters }\end{array}$ & $\begin{array}{c}\text { Normalized } \\
\text { by cluster }\end{array}$ & Normalized \\
\hline A1 & 0.056 & \multirow{3}{*}{0.431} & 0.129 & 0.066 & 0.066 & \multirow{3}{*}{0.377} & 0.175 & 0.079 \\
\hline $\mathrm{A} 2$ & 0.177 & & 0.410 & 0.209 & 0.106 & & 0.281 & 0.127 \\
\hline A3 & 0.199 & & 0.462 & 0.236 & 0.205 & & 0.543 & 0.246 \\
\hline B1 & 0.072 & \multirow{4}{*}{0.262} & 0.274 & 0.085 & 0.044 & \multirow{4}{*}{0.260} & 0.168 & 0.052 \\
\hline B2 & 0.065 & & 0.249 & 0.077 & 0.041 & & 0.158 & 0.049 \\
\hline B3 & 0.062 & & 0.236 & 0.073 & 0.086 & & 0.333 & 0.104 \\
\hline B4 & 0.063 & & 0.241 & 0.075 & 0.089 & & 0.341 & 0.106 \\
\hline I1 & 0.004 & \multirow{3}{*}{0.023} & 0.187 & 0.005 & 0.004 & \multirow{3}{*}{0.026} & 0.168 & 0.005 \\
\hline $\mathrm{I} 2$ & 0.006 & & 0.250 & 0.007 & 0.006 & & 0.233 & 0.007 \\
\hline I3 & 0.013 & & 0.563 & 0.015 & 0.016 & & 0.599 & 0.019 \\
\hline P1 & 0.034 & \multirow{3}{*}{0.128} & 0.267 & 0.041 & 0.046 & 0.169 & 0.273 & 0.056 \\
\hline $\mathrm{P} 2$ & 0.027 & & 0.209 & 0.032 & 0.034 & & 0.203 & 0.041 \\
\hline P3 & 0.067 & & 0.524 & 0.079 & 0.089 & & 0.524 & 0.107 \\
\hline
\end{tabular}




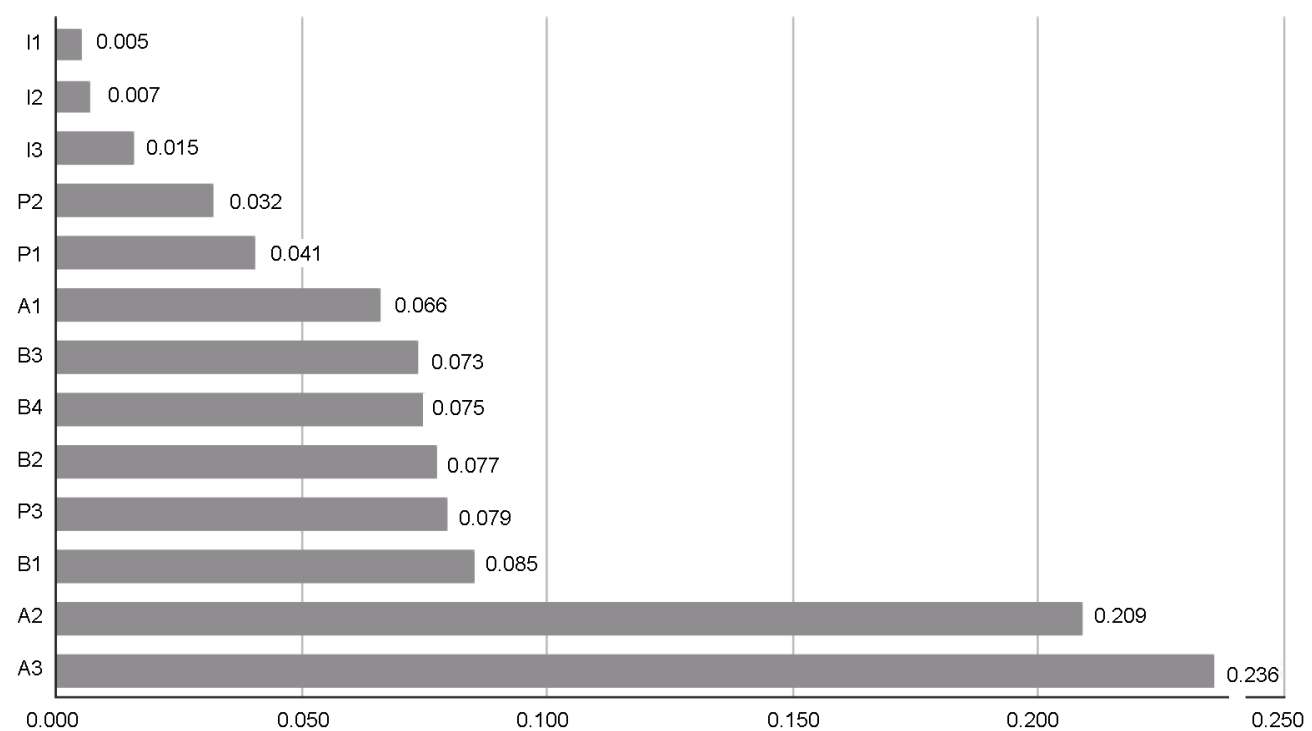

Figure 4. Priority of the factors influencing the development of trust for owners

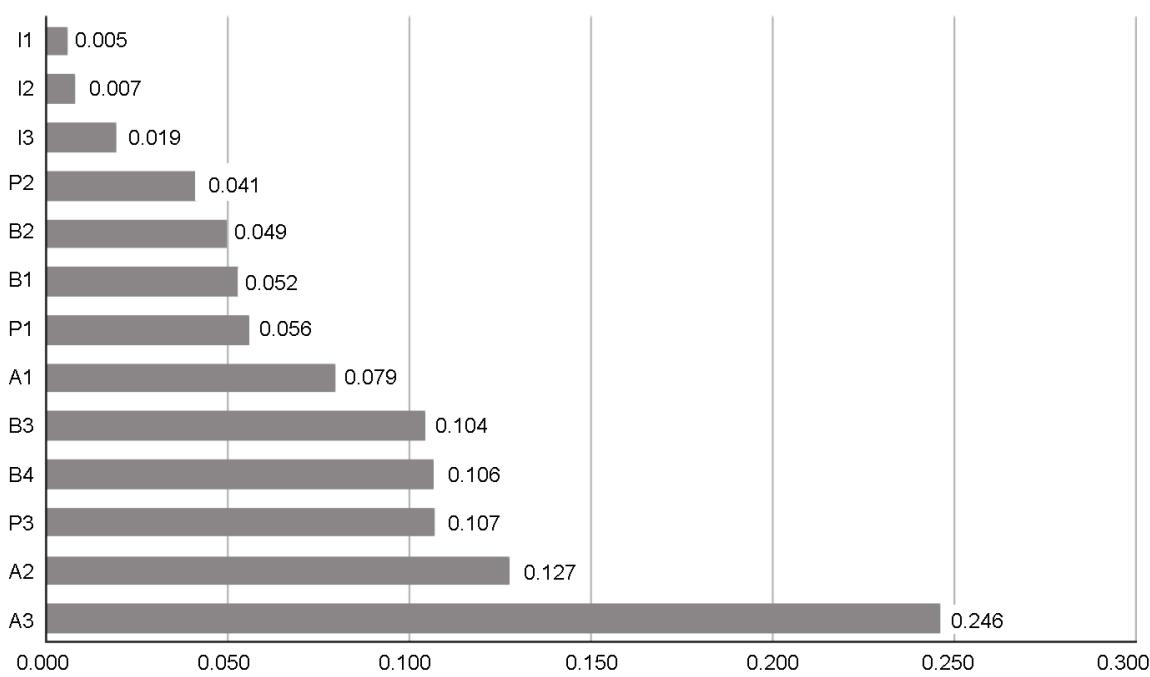

Figure 5. Priority of the factors influencing the development of trust for consultants

relationship (Wagner, Bode 2014), such as being thoughtful and emotional investment. There may be moral hazard and opportunism due to the information asymmetry between owners and consultants. Information availability and information quality somewhat reflect consultants' working attitudes and loyalty. For owners, the weights of information availability, information quality, being thoughtful and emotional investment have little difference (their normalized clusters are $0.274,0.249,0.236$ and 0.241 , respectively). However, consultants' give greater priority to being thoughtful and emotional investment than to information availability and information quality (their normalized clusters are $0.333,0.341,0.168$ and 0.158 , respectively). The partners are familiarized with each other, resulting in possible contingencies around their relationships due to the increased cooperation duration (Mayer,
Argyres 2004). The contractual terms may not contain adequate contingency clauses and may be ineffective in regulating partners' behaviors in the unpredictable environment due to the incomplete contract (Cavusgil et al. 2004; Cao, Lumineau 2015). Meanwhile, drafting a contract in a close and dense Chinese guanxi network may signal that a partner is untrustworthy (Yang et al. 2011; Lovett et al. 1999). In addition, legal provisions are guaranteed in the implemented contract, which are characterized by generality and universality. In contrast, industry practice can better facilitate interactions and understanding between partners through informal activities in the stage of developing trust. The final priorities of factors influencing the development of trust for owners and consultants are shown in Figure 4 and Figure 5, respectively. 
Table 6. The changes in the guanxi elements

\begin{tabular}{|c|c|c|c|c|c|c|c|}
\hline & & \multicolumn{3}{|c|}{ From the owners' perspective } & \multicolumn{3}{|c|}{ From the consultants' perspective } \\
\hline & $\begin{array}{l}\text { Influence } \\
\text { factors }\end{array}$ & $\begin{array}{l}\text { Limit } \\
\text { matrix }\end{array}$ & $\begin{array}{l}\text { Weight of } \\
\text { clusters }\end{array}$ & $\begin{array}{c}\text { Normalized by } \\
\text { cluster }\end{array}$ & $\begin{array}{l}\text { Limit } \\
\text { matrix }\end{array}$ & $\begin{array}{l}\text { Weight of } \\
\text { clusters }\end{array}$ & $\begin{array}{c}\text { Normalized by } \\
\text { cluster }\end{array}$ \\
\hline \multirow{2}{*}{$\begin{array}{l}\text { Initial trust } \\
\text { stage }\end{array}$} & G1 & 0.261 & \multirow{2}{*}{0.354} & 0.736 & 0.275 & \multirow{2}{*}{0.386} & 0.711 \\
\hline & G2 & 0.093 & & 0.264 & 0.112 & & 0.289 \\
\hline \multirow{2}{*}{$\begin{array}{l}\text { Development } \\
\text { trust stage }\end{array}$} & G1 & 0.090 & \multirow{2}{*}{0.155} & 0.579 & 0.091 & \multirow{2}{*}{0.168} & 0.539 \\
\hline & G2 & 0.065 & & 0.421 & 0.077 & & 0.461 \\
\hline
\end{tabular}

\subsection{The transformation of guanxi in different stages of the establishment and maintenance of trust}

The transformation of guanxi is shown in Table 6. The results indicate that the viewpoints of owners and consultants are almost identical. With the accumulation of relationship duration, the weight of guanxi decreases from 0.354 to 0.155 for owners and from 0.386 to 0.168 for consultants. Meanwhile, the guanxi of inter-organizations is transformed from out-group to in-group. For example, from the perspective of owners, the weight of the interorganizations of in-group (G1) decreases from 0.736 in the initial trust stage to 0.579 in the developing trust stage, while the out-group's (G2) weight increases from 0.264 to 0.421 . A certain affinity relationship may already exist by nature, but guanxi also must be established or produced for or by a purpose (Fan 2002) in construction projects. Under the restrictions of the legal conditions, the family guanxi of direct blood, nepotism and in-laws is not allowed in the process of bidding. Thus, inter-organization relationships mainly include other affinity guanxi and business guanxi. The business guanxi is characterized as utilitarian, tactical and opportunistic (Fan 2002). If the partners do not know each other, unfamiliar organizations will be excluded unless they have positive prior experience, good reputation or high prestige. Leung et al. (2011) state that partners' problem-solving attitudes, mianzi and gift-giving build renqing in the new friend stage and the reciprocity of dynamics of renqing enable both partners to accumulate ganqing and become old friends. Thus, the guanxi of the out-group will transform into the in-group due to the increased cooperation duration and trust level. The gap of guanxi between the out-group and in-group will gradually decrease for owners and consultants.

\section{Conclusions}

Our results reveal the priorities of factors influencing trust based on a Sino-German eco-park and explore how these factors influence trust at different stages from different perspectives. In the initial trust stage of the construction project, owners' perspectives show that the priority of factors influencing trust takes the following order: ability, integrity, personal propensity and benevolence. In addition, consultants state that integrity is more important than ability because they have little chance to change contractual agreements unless they are successfully rene- gotiated. In the ability cluster, owners are more focused on consultants' enterprise qualifications and knowledge. However, consultants are more concerned about owners' enterprise qualifications. Due to information asymmetry, owners make up for their faults with the professional knowledge of consultants. Meanwhile, consultants will gain corresponding benefits from owners. Thus, the partners are interdependent. Previous findings suggest that prior experience has a vital influence on trust but ignore the fact that partners may lack cooperative experience in construction projects.

In the process of maintaining trust, the views of owners and consultants are almost identical. Their views suggest that the prioritization of factors influencing trust follows the order ability, benevolence, personal propensity and integrity. The owners evaluate consultants' trustworthiness mainly by their knowledge ability, information availability and information quality. These factors are also basic determinants of whether consultants are given the ability to exercise power on behalf of owners. Meanwhile, information availability and quality also represent consultants' loyalty and attitude in the process of accumulating trust. Owners measure consultants' knowledge first based on enterprise qualifications and later based on actions, such as communications, being thoughtful and emotional investment. In China, cultivating trust is a time-consuming task. Communication is a vital factor since a repeat interaction will increase understanding and emotions while simultaneously promoting the development of trust. Meanwhile, mutual understanding and emotions may restore a victim's trust in an offender because the victim may choose to forgive an offender if the offender makes promises and cooperation actions in the future. The proverb "Time will reveal a person's heart" means that a person needs a long time to estimate the trustworthiness of his/her partner based on factors such as being thoughtful and emotional investment. Comparatively speaking, personal propensity and integrity seem to be less important in developing trust. As a whole, the ordering of the factors influencing trust conforms to Akrout and Diallo's (2017) findings that the development of trust will transform from calculative trust to cognitive and affective trust over time.

In contrast to the Western relationship context, Chinese guanxi networks are a self-defense mechanism among organizations of out-groups and institutional support mechanisms among organizations of in-groups. With 
the increase of cooperation duration, mianzi and renqing are very special factors involved in the guanxi transformation. Maintaining mianzi and accumulating renqing can support harmonious cooperation, increase trust and improve project performance in a short time. Furthermore, these factors protect the enterprise's reputation and may increase the chances for future development. This is especially important in international projects that face greater uncertainties in inter-organizational relations caused by different cultures and institutions. Guanxi is one of the most prominent representatives of Chinese culture, and it affects Chinese social exchange. Partners, especially crossborder inter-organizational partners, should pay particular attention to the impact of Chinese culture on interorganizational exchange.

This study contributes to understanding the establishment and maintenance of trust in different stages, but certain limitations require future research. Frist, while we obtained the relative priorities of the factors influencing trust based on pairwise comparisons, we did not explore the relationships among these factors. Further research must investigate how these factors impact each other. Second, our results only illustrated the transformation of guanxi for the process of developing trust but did not clarify clearly how trust and its influencing factors drive the transformation of guanxi. Third, our findings have regional limitations in that we only address a Sino-German eco-park project. This paper provides experiences and references for future practice.

\section{Acknowledgements}

The authors want to express their gratitude for the key collaboration with the members of the expert panel as well as the support of the Research Institute of Project Administration and Management of Shandong Jianzhu University in this research.

\section{Disclosure Statement}

The authors state that there are no competing financial, professional, or personal interests involving other parties in this research.

\section{References}

Akrout, H.; Diallo, M. F. 2017. Fundamental transformations of trust and its drivers: A multi-stage approach to business-tobusiness relationships, Industrial Marketing Management 66: 159-171. https://doi.org/10.1016/j.indmarman.2017.08.003

Alexopoulos, A. N.; Buckley, F. 2013. What trust matters when: The temporal value of professional and personal trust for effective knowledge transfer, Group and Organization Management 38(3): 361-391. https://doi.org/10.1177/1059601113488939

Aragonés-Beltrán, P.; Chaparro-González, F.; Pastor-Ferrando, J. P.; Pla-Rubio, A. 2014. An AHP (Analytic Hierarchy Process)/ ANP (Analytic Network Process)-based multi-criteria decision approach for the selection of solar-thermal power plant investment projects, Energy 66(2): 222-238.

http://dx.doi.org/10.1016/j.energy.2013.12.016
Aragonés-Beltrán, P.; García-Melón, M.; Montesinos-Valera, J. 2017. How to assess stakeholders' influence in project management? A proposal based on the Analytic Network Process, International Journal of Project Management 35(3): 451-462. http://dx.doi.org/10.1016/j.ijproman.2017.01.001

Argyres, N.; Mayer, K. J. 2007. Contract design as a firm capability: An integration of learning and transaction cost perspectives, Academy of Management Review 32(4): 1060-1077. https://doi.org/10.5465/AMR.2007.26585739

Arrighetti, A.; Bachmann R.; Deakin, S. 1997. Contract law, social norms and inter-firm cooperation, Cambridge Journal of Economics 21(2): 171-195.

https://doi.org/10.1093/oxfordjournals.cje.a013665

Aubert, B. A.; Kelsey, B. L. 2000. The illusion of trust and performance, Cirano Working Papers 12(3): 353-358.

Badi, S.; Wang, L.; Pryke, S. 2017. Relationship marketing in Guanxi networks: A social network analysis study of Chinese construction small and medium-sized enterprises, Industrial Marketing Management 60: 204-218.

http://dx.doi.org/10.1016/j.indmarman.2016.03.014

Blau, P. M. 1965. Exchange and power in social life, American Journal of Sociology 71(3): 333-334. https://doi.org/10.1086/224096

Buvik, M. P.; Rolfsen, M. 2015. Prior ties and trust development in project teams - A case study from the construction industry, International Journal of Project Management 33(7): 1484-1494. http://dx.doi.org/10.1016/j.ijproman.2015.06.002

Campo, J. D. S. P. G.; Pardo, I. P. G.; Perlines, F. H. 2014. Influence factors of trust building in cooperation agreements, Journal of Business Research 67(5): 710-714. http://dx.doi.org/10.1016/j.jbusres.2013.11.032

Cao, Z.; Lumineau, F. 2015. Revisiting the interplay between contractual and relational governance: A qualitative and metaanalytic investigation, Journal of Operations Management 33: 15-42. http://dx.doi.org/10.1016/j.jom.2014.09.009

Cavusgil, S. T.; Deligonul, S.; Zhang, C. 2004. Curbing foreign distributor opportunism: An examination of trust, contracts, and the legal environment in international channel relationships, Journal of International Marketing 12(2): 7-27. http://dx.doi.org/10.1509/jimk.12.2.7.32902

Chen, C.; Zhu, X.; Ao, J.; Cai, L. 2013. Governance mechanisms and new venture performance in China, Systems Research and Behavioral Science 30(3): 383-397. http://dx.doi.org/10.1002/sres.2178

Chen, S. H.; Hong, T. L. 2007. Performance evaluation model for project managers using managerial practices, International Journal of Project Management 25(6): 543-551. https://doi.org/10.1016/j.ijproman.2007.03.004

Chen, Z.; Li, H.; Ren, H.; Xu, Q.; Hong, J. 2011. A total environmental risk assessment model for international hub airports, International Journal of Project Management 29(7): 856-866. https://doi.org/10.1016/j.ijproman.2011.03.004

Cheung, S. O.; Wei, K. W.; Yiu, T. W.; Pang, H. Y. 2011. Developing a trust inventory for construction contracting, International Journal of Project Management 29(2): 184-196. https://doi.org/10.1016/j.ijproman.2010.02.007

Cropanzano, R.; Mitchell, M. S. 2005. Social exchange theory: An interdisciplinary review, Journal of Management 31(6): 874-900. https://doi.org/10.1177/0149206305279602

Dawes, P. L.; Massey, G. R. 2005. Antecedents of conflict in marketing's cross-functional relationship with sales, European Journal of Marketing 39: 1327-1344.

http://dx.doi.org/10.1108/03090560510623280 
Dyer, J. H.; Chu, W. 2000. The determinants of trust in supplierautomaker relationships in the US, Japan, and Korea, Journal of International Business Studies 42(1): 10-27. https://doi.org/10.1057/jibs.2010.34

Emmers-Sommer, T. M. 2004. The effect of communication quality and quantity indicators on intimacy and relational satisfaction, Journal of Social and Personal Relationships 21(3): 399-411. https://doi.org/10.1177/0265407504042839

Fan, Y. 2002. Questioning guanxi: definition, classification and implications, International Business Review 11(5): 543-561. https://doi.org/10.1016/S0969-5931(02)00036-7

Ghosh, A.; Fedorowicz, J. 2008. The role of trust in supply chain governance, Business Process Management Journal 14(4): 453470. https://doi.org/10.1108/14637150810888019

Girmscheid, G.; Brockmann, C. 2010. Inter and intraorganizational trust in international construction joint ventures, Journal of Construction Engineering and Management 136(3): 353360. https://doi.org/10.1061/(ASCE)CO.1943-7862.0000142

Gulati, R. 1995. Does familiarity breed trust? The implications of repeated ties for contractual choice in alliances, Academy of Management Journal 38(1): 85-112.

Hallikas, J.; Virolainen, V. M.; Tuominen, M. 2002. Risk analysis and assessment in network environments: A dyadic case study, International Journal of Production Economics 78(1): 45-55. https://doi.org/10.1016/S0925-5273(01)00098-6

Hammond, S. C.; Glenn, L. M. 2004. The ancient practice of Chinese social networking: Guanxi and social network theory, Emergence Complexity and Organization 6(1): 24-31.

Harris, S.; Dibben, M. 1999. Trust and co-operation in business relationship development: Exploring the influence of national values, Journal of Marketing Management 15(6): 463-483. http://dx.doi.org/10.1362/026725799785045851

Hwang, K. K. 1987. Face and favor: The Chinese power game, American Journal of Sociology 92(4): 944-974. https://doi.org/10.1086/228588

Jin, X. H.; Ling, F. Y. Y. 2005. Model for fostering trust and building relationships in China's construction industry, Journal of Construction Engineering and Management 131(11): 1224-1232. https://doi.org/10.1061/(ASCE)07339364(2005)131:11(1224)

Joskow, P. L. 1987. Contract duration and relationship-specific investments: empirical evidence from coal markets, American Economic Review 77(1): 168-185.

Kadefors, A. 2004. Trust in project relationships - inside the black box, International Journal of Project Management 22(3): 175-182. https://doi.org/10.1016/S0263-7863(03)00031-0

Kwon, I. G.; Suh, T. 2004. Factors affecting the level of trust and commitment in supply chain relationships, Journal of Supply Chain Management 40(2): 4-14.

https://doi.org/10.1111/j.1745-493X.2004.tb00165.x

Kwon, I. G.; Suh, T. 2005. Trust, commitment and relationships in supply chain management: a path analysis, Supply Chain Management 10(1): 26-33. https://doi.org/10.1108/13598540510578351

Laan, A. T.; Voordijk, J. T.; Noorderhaven, N. G.; Dewulf, G. P. M. R. 2012. Levels of interorganizational trust in construction projects: Empirical evidence, Journal of Construction Engineering and Management 138(7): 821-831. https://doi.org/10.1061/(ASCE)CO.1943-7862.0000495

Lee, J.; Park, J. G.; Lee, S. 2015. Raising team social capital with knowledge and communication in information systems development projects, International Journal of Project Management 33(4): 797-807.

https://doi.org/10.1016/j.ijproman.2014.12.001
Leung, T. K. P.; Chan, Y. K.; Lai, K. H.; Ngai, E. W. T. 2011. An examination of the influence of guanxi and xinyong (utilization of personal trust) on negotiation outcome in China: An old friend approach, Industrial Marketing Management 40(7): 1193-1205. https://doi.org/10.1016/j.indmarman.2010.12.020

Lovett, S.; Simmons, L. C.; Kali, R. 1999. Guanxi versus the market: ethics and efficiency, Journal of International Business Studies 30(2): 231-247. https://doi.org/10.1057/palgrave.jibs.8490068

Lumineau, F; Henderson, J. E. 2012. The influence of relational experience and contractual governance on the negotiation strategy in buyer-supplier disputes, Journal of Operations Management 30(5): 382-395.

https://doi.org/10.1016/j.jom.2012.03.005

Luo, Y. 1997. Guanxi: Principles, philosophies, and implications, Human Systems Management 16(1): 43-51.

Lusch, R. F.; Brown, J. R. 1996. Interdependency, contracting, and relational behavior in marketing channels, Journal of Marketing 60(4): 19-38. https://doi.org/10.2307/1251899

Maurer, I. 2010. How to build trust in inter-organizational projects: The impact of project staffing and project rewards on the formation of trust, knowledge acquisition and product innovation, International Journal of Project Management 28(7): 629-637. https://doi.org/10.1016/j.ijproman.2009.11.006

Mayer, K. J.; Argyres, N. S. 2004. Learning to contract: Evidence from the personal computer industry, Organization Science 15(4): 394-410. https://doi.org/10.1287/orsc.1040.0074

Mayer, R. C.; Davis, J. H.; Schoorman, F. D. 1995. An integrative model of organizational trust: Past, present, and future, Academy of Management Review 20(3): 709-734. https://doi.org/10.5465/amr.1995.9508080335

Mesquita, L. F.; Brush, T. H. 2008. Untangling safeguard and production coordination effects in long-term buyer-supplier relationships, Academy of Management Journal 51(4): 785-807. https://doi.org/10.5465/AMJ.2008.33665612

Park, J. G.; Lee, J. 2014. Knowledge sharing in information systems development projects: Explicating the role of dependence and trust, International Journal of Project Management 32(1): 153-165. https://doi.org/10.1016/j.ijproman.2013.02.004

Patnayakuni, R.; Rai, A.; Tiwana, A. 2007. Systems development process improvement: A knowledge integration perspective, IEEE Transactions on Engineering Management 54(2): 286300. https://doi.org/10.1109/TEM.2007.893997

Peng, M. W.; Luo, Y. 2000. Managerial ties and firm performance in a transition economy: The nature of a micro-macro link, Academy of Management Journal 43(3): 486-501.

Poppo, L.; Zhou, K. Z.; Rhu, S. 2008. Alternative origins to interorganizational trust: An interdependence perspective on the shadow of the past and the shadow of the future, Organization Science 19(1): 39-55. https://doi.org/10.1287/orsc.1070.0281

Rezvani, A.; Chang, A.; Wiewiora, A.; Ashkanasy, N. M.; Jordan, P. J.; Zolin, R. 2016. Manager emotional intelligence and project success: The mediating role of job satisfaction and trust, International Journal of Project Management 34(7): 1112-1122. https://doi.org/10.1016/j.ijproman.2016.05.012

Saaty, T. L. 2004. Fundamentals of the analytic network process - multiple networks with benefits, costs, opportunities and risks, Journal of Systems Science and Systems Engineering 13(3): 348-379. https://doi.org/10.1007/s11518-006-0171-1

Saaty, T. L.; Sagir, M. 2009. Extending the measurement of tangibles to intangibles, International Journal of Information Technology and Decision Making 8(1): 7-27. https://doi.org/10.1142/S0219622009003247 
Seggie, S. H.; Griffith, D. A.; Jap, S. D. 2013. Passive and active opportunism in interorganizational exchange, Journal of Marketing 77(7): 73-90. https://doi.org/10.1509/jm.11.0529

Styles, C.; Ambler, T. 2003. The coexistence of transaction and relational marketing: Insights from the Chinese business context, Industrial Marketing Management 32(8): 633-642. https://doi.org/10.1016/j.indmarman.2003.06.004

Sullivan, J.; Peterson, R. B. 1982. Factors associated with trust in Japanese-American joint ventures, Management International Review 22(2): 30-40. https://doi.org/10.2307/40227633

Thorgren, S.; Wincent, J. 2011. Interorganizational trust: Origins, dysfunctions and regulation of rigidities, British Journal of Management 22: 21-41. https://doi.org/10.1111/j.1467-8551.2010.00717.x

Triandis, H. C. 1989. The self and social behavior in differing cultural contexts, Psychological Review 96(3): 506-520. https://doi.org/10.1037/0033-295X.96.3.506

Tzafrir, S. S.; Harel, T. L. G. H.; Baruch, Y.; Dolan, S. L. 2004. The consequences of emerging HRM practices for employees' trust in their managers, Personnel Review 33(6): 628-647. https://doi.org/10.1108/00483480410561529

Uzzi, B.; Lancaster, R. 2003. Relational embeddedness and learning: The case of bank loan managers and their clients, Management Science 49(4): 383-399. https://doi.org/10.1287/mnsc.49.4.383.14427

Wagner, S. M.; Bode, C. 2014. Supplier relationship-specific investments and the role of safeguards for supplier innovation sharing, Journal of Operations Management 32(3): 65-78. https://doi.org/10.1016/j.jom.2013.11.001

Wang, C. L. 2007. Guanxi vs relationship marketing: Exploring underlying differences, Industrial Marketing Management 36(1): 81-86. https://doi.org/10.1016/j.indmarman.2005.08.002

Wei, K. W.; Cheung, S. O.; Yiu, T. W.; Pang, H. Y. 2008. A framework for trust in construction contracting, International Journal of Project Management 26(8): 821-829. https://doi.org/10.1016/j.ijproman.2007.11.004

Williamson, O. E. 2000. The new institutional economics: Taking stock, looking ahead, Journal of Economic Literature 38(3): 595-613. https://doi.org/10.1257/jel.38.3.595

Yang, Z.; Zhou, C.; Jiang, L. 2011. When do formal control and trust matter? A context-based analysis of the effects on marketing channel relationships in China, Industrial Marketing Management 40(1): 86-96. https://doi.org/10.1016/j.indmarman.2010.09.013

Yuan, L.; Xie, E.; Teo, H. H.; Peng, M. W. 2010. Formal control and social control in domestic and international buyer-supplier relationships, Journal of Operations Management 28(4): 333-344. https://doi.org/10.1016/j.jom.2009.11.008

Zhou, K. Z.; Poppo, L. 2010. Exchange hazards, relational reliability, and contracts in China: The contingent role of legal enforceability, Journal of International Business Studies 41(5): 861-881. https://doi.org/10.1057/jibs.2010.7 